At least so I understand his letter in NATURE, vol. xxx. p. 536 . If that statement or conclusion is perfectly correct, I must of course allude to it in the next edition of my Pyramid book, and adopt its corrections, whatever they may lead to; so that it is well at once to ask any further questions which seem demanded for full trust and credibility.

That the observations made at Greenwich during the last forty-seven years, when computed as the said Astronomer-Royal has computed them, do not show any change of latitude during that space of time, no one is more ready to allow most honourably than myself. But before we can admit that that result, pure and simple, absolutely establishes the non-shifting of the earth's axis of rotation, two more things at least must come about, viz. :-

First, the Astronomer-Royal must attack and demolish the observations and calculations made at the great Russian Observatory of Pulkowa, which show that such a change, at the rate of about one foot per annum, has been going on through the last quarter of a century, and are even believed in America to be more accurate than the Greenwich observations. And

Second, he must take up, and similarly destroy, the testimony of the earlier Greenwich observations themselves, before these last forty-seven years of his own computation began.

Now those earlier Greenwich observations were so remarkable for what they did indicate in their own time, that I may freely mention now, secing that all the parties are dead, that somewhere about 1836 , Sir Thomas, then Mr. Maclear, at the Royal Observatory, Cape of Good Hope, received a private letter from Thomas Glanville Taylor, Honourable East India Company's Astronomer at Madras---and carlier an assistant at the Royal Observatory, Greenwich-stating his belief that the latitude of the British National Observatory was continually decreasing; and he gave a list of latitudes, as determined by Grecnwich observations, so far back as they went, but condensed into three epochs, to prove the point.

The matter was kindly communicated to me by my then chief, Sir Thomas Maclear, and was of course deemed interesting and curious at the time; but had quite gone to rest in my mind, until twenty-nine years afterwards, when I fell across the same effect, in the same direction and at nearly the same rate, but through a longer period of time and to a much larger accumulated quantity, at the Great Fyramid of Geezeh in Egypt. The datum for the latitude of 4000 years ago, to compare with the present observed latitule of the same spot-though exactly that which the learned Dr. Hook desired so much, but in vain, to find anywhere 200 years ago-is not perhaps so purely and perfectly scientific as the high-class practical astronomers of our times will always condescend to notice. But in the accompanying feature of change of azimuth, so creditably brought to the front by $\mathrm{Mr}$. Flinders Petrie, there is a testimony of modern observation to ancient accuracy of so respectable a character-if I may be allowed so to say--that it ought not to be entirely ignored; and it was first mentioned thus.

While I was at the Great Pyramid in 1865 , and just after I had there measured the azimuths of the entrance-passages of the Great and Second Pyramids on successive evenings by reference to the six-hour elongations of Polaris, there came a letter from a retired civil engineer in Edinburgh, a man of long Batavian experience in his day, and gifted with remarkable powers of modern science and originality of mind,-in which letter he was pleased to run down all the presumed object of my work out there on the Geezeh Hill. Especially too was he pungent on the point that even the best of the ancients had not that triumph of modern civilisation, "the manufacturing principle," in them; "for," said he, "they could not make two things alikc."

Whereupon I sent him the azimuths of the entrance-passages of those two grand pyramids, so many hundred feet apart, and pointed out, that, though they showed an error of azimuth for modern date of nearly five minutes, yet the one pyramid exhibited so very ncarly the same identical quantity as the other, that they werc, angularly, nearer together, or more exactly alike, than were the two halves of one and the same azimuth circle I was observing with. And yet that circle was by so celebrated a maker of modern times as Troughton, and the instrument a choice one specially made by him to be presented to the cclehrated Prof. Playfair, by his admiring students in the University of Edinburgh ; and by Playfair's executors, again, presented after his death to the Royal Observatory, Edinburgh, where it is still preserved in honour.

15, Royal Terrace, Edinburgh, October ro

\section{The Sky-Glows}

IN reply to Mr. Backhouse's question (p. 5II) as to where the context of Mr. Neison's remarks can be seen, I can only say that I do not know. I came across the portion quoted relating to these phenomena at the end of the Astronomer-Royal's Report upon the Weather of I883. Like Mr. Backhouse, I have been on the look-out for solar halos, or big rings round the sun as we call them, for the last thirty years, more with a view to be prepared for squalls, \&c., when boating, than anything else. But for some years there has been so much haze about the sun, and the weather has so often cried "Wolf," so to speak, with no responding gale or squall, that of late I have ceased to take much note of such warnings, I may here mention that the rosy corona, when visible, as it so often is now, can be well seen by looking towards the place of the sun, but standing in the shadow of some high building; or at times by totally eclipsing the sun with a hat held between him and the eye.

As far back as January I, r884, in a letter to the St. James's Gazelte, I ventured to predict that we had not seen the last of what were then spoken of as the "Recent Sunsets"; there was a very remarkable after-glow ten days after this, reaching the zenith, seen even in London. In the same letter of January I, I suggested some increase in solar energy as the cause of these phenomena.

For some time, though feebler repetitions of the glows continued to be seen up to the end of March, there was nothing strong enough in the way of colour worth noting. But from what I continued to see in the shape of vapour, together with that strange warm colour by day about the sun, I felt sure that whatever might be the cause of those phenomena must still be going on, and in a short note dated April 12 , I again spoke of their probable early reappearance. A graphic account of these after-glows, written by an observer at Smyrna, appeared in the St. James's Garette of February 25, in which he pointed out what I have often since noticed, viz. that with excess of moisture all colour disappears.

This was at times very remarkable in the early part of July this year, when we had some of the strangest white sunsets I have ever seen. The sky around and above where the sun had set, looking almost cciling-like in its opacity, upon which soon appeared numbers of weird small cloud forms, at times very regular, like ripple-marks in sand, or the bones of some great fish or saurian embedded on a slab of stone.

Against these pale sunsets all buildings and trees told like black velvet, while the clouds would rest almost stationary for a long time. Years back such a sky would have betokened a hurricane; but evening after evening they were repeated, and no storm of any importance followed. For many years past, but notably during the summer of 1883 , I had observed a steady increase in a white luminous glare about the sun, so much so that I wrote about it in the year I 882 to my brother in India. I was not therefore surprised altogether when as the sunsets increased in colour, which they mostly do in autumn, that this glare last winter was followed by something more than usual in the way of colour ; and here I should like to say that, as far as I have seen, and I have missed very few chances of watching them, that though last winter twilights often increased up to a certain time in strength, yet they did not exceed in duration the time allotted to twilight in the almanacs. This letter is already too long, but I cannot help asking, in conclusion, whether it may not be possible that we have been all along muddling up cause and effect, and that the eruption at Krakatoa, the recent earthquakes and waves, as well as the strange atmospheric phenomena, which are still about us, cannot all be traced to one cause, viz, actual increase of sun power?

Southampton

Robert LesLie

THIs evening after sunset I noticed a column of yellowish light over where the sun had set, and moving with the sun. I have seen the same before. Can it be the zodiacal light? I have frequently noticed during the present year, while the sun was much too high for any sunset colours, a pinkish colour in the sky. This has been observed by others, but I do not know whether it has been seen outside the British Islands. It must be connected with the sunset-glows which several of your correspor dents have Aescribed.

Belfast, October I2 